Łukasz Wróblewski iD http://orcid.org/0000-0002-4465-0107

Akademia WSB, Dąbrowa Górnicza

e-mail: lwroblewski@wsb.edu.pl

\title{
Rola i znaczenie aktywności online użytkowników mediów spolecznościowych w ksztaltowaniu wizerunku instytucji kultury
}

\begin{abstract}
The Role and Importance of the Online Activity of Social Media Users in Shaping the Image of Cultural Institutions
\end{abstract}

The article is of the theoretical and empirical character. In the first part, the definitions, types, components and the process of shaping the image of cultural institutions are discussed. The second part presents research hypotheses, methodology, results, conclusions and the implications for management. The results of the research presented in the article prove that the online activity of social media users stimulates the image of cultural institutions. Statistically significant relationships were observed for the components of the image related to awareness/associations of cultural institution and for the relationship related to the perception of quality its offer.

Keywords: image, social media, cultural institutions, internet users

Słowa kluczowe: wizerunek, media społecznościowe, instytucje kultury, internauci

\section{Pojęcie, rodzaje i komponenty wizerunku instytucji kultury}

W drugiej dekadzie XXI wieku wizerunek ma dla instytucji kultury znaczenie strategiczne. Można mówić o istnieniu sprzężenia zwrotnego. Gdy wizerunek instytucji kultury jest pozytywny, łatwiej jest jej osiągnąć założone cele. Z kolei instytucja kultury, realizując cele, łatwiej zyskuje uznanie wśród potencjalnych i obecnych 
odbiorców jej oferty, artystów, krytyków czy donatorów [Correia, Mateus, Leonor 2015]. Pozytywny wizerunek jest zatem bardzo ważnym kapitałem instytucji, a jego kształtowanie powinno być przedmiotem starannie przygotowanej strategii marketingowej. W strategii tej bardzo istotną rolę do odegrania mają media społecznościowe i ich użytkownicy, co pokazane zostanie w niniejszym artykule.

Przed przystąpieniem do omówienia roli i znaczenia aktywności internautów w mediach społecznościowych w kształtowaniu wizerunku instytucji kultury należy zdefiniować samo pojęcie wizerunku. W literaturze przedmiotu można się bowiem spotkać z wieloma jego definicjami. Definicje te różnią się między sobą głównie perspektywą, z jakiej na własne komunikowanie z szeroko pojętą sferą publiczną patrzą przedstawiciele różnych dziedzin życia społecznego. To powoduje, że podanie jednej obowiązującej definicji, która w sposób maksymalnie zwarty trafnie oddawałaby istotę pojęcia, jest niezwykle trudne czy wręcz niemożliwe. Definicje ogólne określają wizerunek jako subiektywne wyobrażenie o danym obiekcie powstałe w wyniku indywidualnego procesu percepcji [Hartmann 1992: 137]. Według H. Mruka [2012: 154] wizerunek to synteza wyobrażeń, odczuć, oczekiwań, które powstają w efekcie odbieranych bodźców. Wizerunek instytucji kultury można zatem rozumieć jako obraz w naszych głowach [Lippmann 1998: 3-20], wyobrażenie o instytucji i jej ofercie pomagające nam kategoryzować i porządkować to, z czym się stykamy. Inne definicje określają z kolei mianem wizerunku pełną niuansów, względnie trwałą, komunikowalną całość obiektywnych i subiektywnych, a więc i fałszywych, silnie zabarwionych emocjonalnie wyobrażeń, idei, postaw, uczuć, doświadczeń jakiejś osoby lub grupy osób w stosunku do danego obiektu, np. instytucji kultury [Kotler, Haider, Rein 1993: 141]. Na potrzeby niniejszego artykułu przez wizerunek rozumieć będziemy całokształt subiektywnych wyobrażeń rzeczywistości, które wytworzyły się w umysłach ludzkich jako efekt percepcji, oddziaływania środków masowego przekazu i nieformalnych przekazów informacyjnych. W zależności od tego, jak jest kształtowany wizerunek instytucji kultury i jak go odbierają poszczególne grupy interesariuszy, można mówić o następujących jego rodzajach (rys. 1).

W procesie kształtowania wizerunku instytucji kultury szczególnie duże znaczenie ma podział na wizerunek pierwotny i wtórny [Kotler, Haider, Rein 1993]. Pierwszy z nich to wizerunek ukształtowany w umyśle nabywcy poprzez oddziaływanie promocyjne, np. działania promocyjne w mediach społecznościowych. Wizerunek wtórny powstaje, wtedy gdy nabywca osobiście „wypróbuje” produkt, skorzysta $\mathrm{z}$ oferty instytucji kultury.

W ujęciu K.L. Kellera [1993: 1-22], wizerunek instytucji kultury będzie bardzo mocno powiązany z wiedzą na temat instytucji kultury, ze świadomością funkcjonowania instytucji kultury. Z kolei według D.A. Aakera [1991: 1] na wizerunek będzie miał wpływ zestaw komponentów związanych z instytucją kultury, jej nazwa oraz symbol, które dają się dołączyć lub odjąć od ogólnej wartości usługi dla instytucji kultury oraz jej klientów. Aaker wśród komponentów tych umieścił: 
- świadomość instytucji kultury - siła, z jaką instytucja kultury jest obecna w umyśle odbiorcy i potencjalnego odbiorcy oferty instytucji, a zatem odnosi się ona do zdolności rozpoznania lub przypomnienia sobie przez niego określonej instytucji kultury w danej kategorii organizacji czy produktów [Aaker 1996];

- skojarzenia z instytucją kultury - wszystko to, co według odbiorcy, potencjalnego odbiorcy oferty kulturalnej dotyczy instytucji kultury [Aaker 1996]; skojarzenia są związane z powstawaniem wizerunku instytucji kultury w umyśle odbiorcy, potencjalnego odbiorcy oferty, rodzajem instytucji, kategorią produktu, świadomością istnienia instytucji kultury oraz jej cechami, znakami i symbolami [Aaker 2000];

- postrzeganą jakość produktów instytucji kultury - postrzeganie przez odbiorcę, potencjalnego odbiorcę oferty kulturalnej ogólnej jakości usługi instytucji kultury lub przekonanie o jej wyższości w porównaniu z usługami alternatywnymi innych organizacji [Yoo, Donthu 2001: 1-14],

- lojalność wobec instytucji kultury - przywiązanie odbiorcy oferty do instytucji kultury; lojalność odzwierciedla prawdopodobieństwo zmiany instytucji kultury przez odbiorcę oferty na inną, przykładowo wtedy, gdy następuje zmiana ceny jej usług lub składowych wizerunku [Yoo, Donthu 2001: 1-14],

- inne aktywa - będące w szczególności patentami, znakami towarowymi oraz relacjami zachodzącymi w kanałach dystrybucji.

Zaprezentowane w artykule wyniki badań odnoszą się do pierwszych czterech komponentów mających znaczenie w kształtowaniu wizerunku instytucji kultury, co jest powszechnie stosowane w badaniach dotyczących organizacji usługowych. Dotychczas prowadzone badania dowodzą również, że świadomość instytucji oraz skojarzenia z instytucją mogą być połączone w jedną składową [Yoo, Donthu 2001: 1-14],

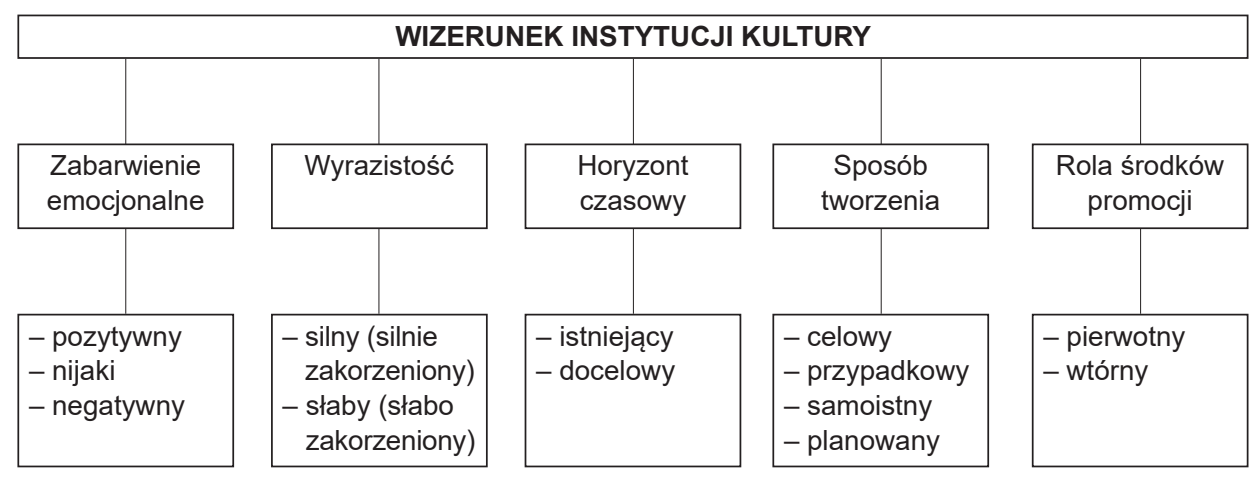

Rys. 1. Rodzaje wizerunku instytucji kultury

Źródło: opracowanie własne na podstawie Hartmann 1992; Kotler, Haider, Rein 1993; Lippmann 1998; Mruk 2012. 
dlatego też $\mathrm{w}$ artykule te dwa komponenty będą rozpatrywane łącznie. Wyniki badań dotyczą instytucji kultury rozumianych w sposób tradycyjny, co znaczy, że przez instytucję kultury rozumieć tu należy podmiot posiadający osobowość prawną (którą nabywa $\mathrm{z}$ chwilą wpisania do rejestru instytucji kultury), powołany w celu prowadzenia działalności kulturalnej. W Polsce będą to w szczególności filharmonie i orkiestry, opery i operetki, teatry, muzea, galerie, kina, ośrodki, centra i domy kultury, biblioteki, instytucje ochrony i dokumentacji zabytków.

\section{Miejsce i znaczenie mediów spolecznościowych w procesie ksztaltowania wizerunku instyfucji kultury}

Proces kształtowania wizerunku instytucji kultury obejmuje zagadnienia jego powstawania i zmiany. $Z$ definicji wynika, iż jest on kategorią względnie trwałą, co oznacza, że raz ukształtowany okazuje się trudny do zmiany w krótkim czasie. Przyjmuje się jednak, że w długim okresie zmiana wizerunku jest możliwa poprzez systemowe i konsekwentne działania, również te podejmowane w przestrzeni mediów społecznościowych. Profesjonalne podejście do kształtowania wizerunku instytucji kultury związane jest jednak z realizacją kilku kluczowych etapów zaprezentowanych na rysunku 2. Ważne miejsce $\mathrm{w}$ tym procesie zajmują media społecznościowe oraz ich użytkownicy [Smith, Zook 2011].

Proces kształtowania wizerunku instytucji kultury rozpoczyna się od analizy obecnego wizerunku - w tym celu konieczne jest m.in. dokonanie inwentaryzacji zasobów instytucji (ludzkich, rzeczowych, finansowych, informacyjnych) znajdujących się w jej dyspozycji, przeprowadzenie analizy mocnych i słabych stron instytucji. Pomocna w tym procesie może być analiza SWOT [Selase 2018: 3830-3832]. Prawidłowe zastosowanie tego narzędzia może mieć istotny wpływ na powodzenie kampanii wizerunkowej, może być również bardzo użyteczne w procesie analizy zasobów i otoczenia instytucji kultury oraz określenia priorytetów działania. W celu uzyskania jasnego opisu sytuacji, traktuje się atuty i słabości jako czynniki wewnętrzne z punktu widzenia instytucji, na które organizacja ma wpływ, a szanse i zagrożenia jako czynniki zewnętrzne znajdujące się w otoczeniu. Poprzez jasne określenie atutów i możliwości da się stworzyć i wykorzystać nowe koncepcje i plany mogące mieć istotne znaczenie w procesie zmiany wizerunku. Źródła słabości i zagrożeń również należy ustalić. Niektóre ze słabości mogą bowiem być kontrolowane i z łatwością skorygowane, inne mogą znajdować się jednak poza zasięgiem kontroli instytucji kultury.

Kolejnym etapem w kształtowaniu wizerunku instytucji kultury jest wybór adresatów działań marketingowych [Golinowski 2005]. Opracowana kampania wizerunkowa, powinna obejmować swoim oddziaływaniem przede wszystkim takie grupy docelowe jak: 
- odbiorcy oferty instytucji kultury (zarówno ci obecni, jak i potencjalni),

- artyści (twórcy, odtwórcy) oraz pozostali pracownicy instytucji kultury,

- donatorzy (sponsorzy, mecenasi i darczyńcy),

- krytycy sztuki,

- media,

- władza samorządowa, wojewódzka oraz centralna,

- społeczność lokalna i regionalna,

- turyści krajowi i zagraniczni,

- inne instytucje kultury.

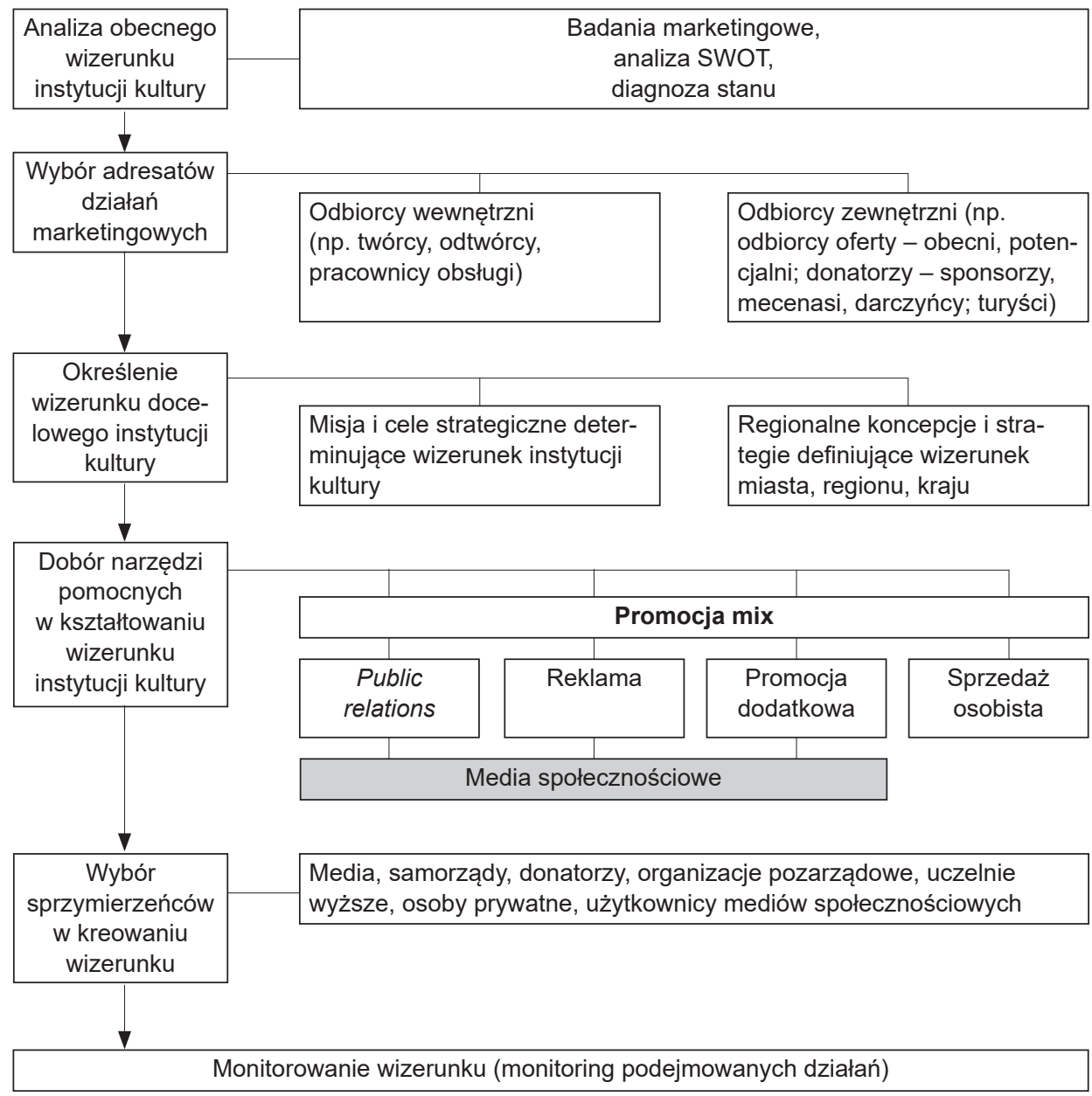

Rys. 2. Miejsce mediów społecznościowych w procesie kształtowania wizerunku instytucji kultury

Źródło: opracowanie własne na podstawie Budzyński 2003, Murdoch 2003, Golinowski 2005, Szyszka 2013, Selase 2018. 
Równie ważnym etapem w procesie kształtowania wizerunku instytucji kultury jest określenie wizerunku docelowego. W. Budzyński [2003: 16-17] wyróżnia cztery jego rodzaje:

- wizerunek rzeczywisty (obcy), który można zdefiniować jako rzeczywisty obraz instytucji kultury wśród stykających się z nią osób (np. odbiorców oferty artystycznej);

- wizerunek lustrzany (własny), będący obrazem instytucji kultury wśród jej pracowników;

- wizerunek pożądany, określający, jak menedżerowie instytucji kultury chcieliby widzieć swoją instytucję lub jak uważają, że powinno ją widzieć otoczenie;

- wizerunek optymalny, będący optymalnym kompromisem pomiędzy trzema wyżej wymienionymi rodzajami wizerunku, który jest możliwy do osiągnięcia w danych warunkach.

Wizerunkiem docelowym instytucji kultury będzie zazwyczaj wizerunek pożądany (np. instytucja kultury otwarta na ludzi młodych, instytucja kultury prezentująca muzykę najnowszą, instytucja kultury wyznaczająca trendy w sztuce współczesnej). Bardzo często jest on zdefiniowany, określony w statucie czy strategii rozwoju organizacji.

Dobór narzędzi to kolejny etap w procesie kształtowania wizerunku instytucji kultury. Do narzędzi tych należą przede wszystkim instrumenty marketingu mix (produkt, cena, dystrybucja, promocja), w szczególności będą to jednak klasyczne formy promocji takie, jak: public relations, reklama, promocja dodatkowa oraz sprzedaż osobista. Należy przy tym pamiętać, że dobrze przygotowana kampania promocyjna instytucji kultury ukierunkowana na zmianę wizerunku powinna uwzględniać również działania w mediach społecznościowych, takich jak chociażby Facebook, Twitter, Instagram czy YouTube [Killian, McManus 2015]. Media te odróżnia od innych instrumentów promocji sprzężenie zwrotne. Komunikat nadawany za ich pośrednictwem trafia bowiem od nadawcy do odbiorcy, po czym odbiorca ma możliwość udzielenia odpowiedzi nadawcy w czasie rzeczywistym [Mazurek-Łopacińska, Sobocińska 2017: 343-352; Grzesiak 2018]. Co więcej, to właśnie sami internauci są bardzo często aktywnymi twórcami komunikatów dotyczących instytucji kultury, które publikowane są na portalach społeczościowych (zarówno własnych, jak i innych) [Kaplan, Haenlein 2010]. Według D.G. Muntinga, M. Moorman i E.G. Smit [2011: 13-46] zachowania internautów mające wpływ na wizerunek instytucji kultury można podzielić na:

- konsumpcję - wymagającą jedynie pasywnego odbioru treści związanych z określoną instytucją kultury, umieszczonych w sieci przez pracowników instytucji kultury lub przez innych internautów, np. oglądanie zdjęć, filmów, przeglądanie ocen i komentarzy na temat instytucji kultury, czytanie dyskusji dotyczących organizowanych przez instytucję eventów toczących się na portalach społecznościowych [Schivinski, Brzozowska-Woś 2015: 77-85]; 
- kontrybucję - przyczyniającą się do powstawania dodatkowych treści związanych $\mathrm{z}$ instytucją kultury m.in. poprzez uczestnictwo w dyskusjach dotyczących organizowanych przez instytucję eventów na stronach gromadzących ich fanów, pisanie komentarzy na temat instytucji kultury lub dodawanie treści ich dotyczących (np. zdjęć, grafik, filmów) na blogach oraz stronach skupiających fanów organizacji (fanpage) [Shao 2009];

- kreację - polegającą na tworzeniu i publikowaniu w sieci treści dotyczących instytucji kultury, które później będą konsumowane lub kontrybuowane przez innych (np. prowadzenie blogów poświęconych konkretnym instytucjom kultury, publikowanie recenzji organizowanych przez instytucję eventów, tworzenie i umieszczanie w sieci filmów, zdjęć, grafik czy plików dźwiękowych związanych z instytucją kultury).

Kształtowanie wizerunku instytucji kultury z zastosowaniem mediów społecznościowych okaże się jednak skuteczne tylko wtedy, jeśli realizowane będzie w sposób planowy i systemowy. Dlatego też bardzo ważne jest, by przypadkowe i jednorazowe inicjatywy zamienić na działania cykliczne i powtarzalne [Szyszka 2013].

Jednym $\mathrm{z}$ ważniejszych etapów kampanii wizerunkowej jest zidentyfikowanie sprzymierzeńców w kształtowaniu pożądanego wizerunku instytucji kultury [Murdoch 2003]. Rodzi się on w skomplikowanym procesie, w którym uczestniczą pracownicy instytucji, odbiorcy oferty kulturalnej, media, tzw. ludzie świata sztuki (np. krytycy sztuki), donatorzy, wreszcie użytkownicy mediów społecznościowych, którzy w sieci konsumują, rozpowszechniają bądź kreują treści dotyczące instytucji kultury. Sprzymierzeńcy mają wpływ na takie komponenty wizerunku, jak świadomość instytucji kultury, jej rozpoznawalność, postrzeganie jakości oferty instytucji kultury czy lojalność wobec instytucji kultury [Wróblewski i in. 2018].

Pomimo że wizerunek instytucji kultury z zastosowaniem mediów społecznościowcych można kształtować dowolnie - utrwala się on bowiem w wyniku subiektywnego postrzegania stanu rzeczy - należy pamiętać, że obraz utrwalony nie jest stały. Nie jest też jednolity, gdyż powstaje w umysłach poszczególnych jednostek, które tworzą otoczenie. Dlatego też niezbędny jest stały monitoring podejmowanych działań.

\section{Hipotezy badawcze oraz metodyka prowadzonych badań}

Na potrzeby prowadzonych badań zgodnie z koncepcją D.G. Muntinga, M. Moorman i E.G. Smit [2011: 13-46] przyjęto założenie, że aktywność online internautów w mediach społecznościowych przejawia się na trzech różnych poziomach (konsumpcji, kontrybucji i kreacji). W opinii autora aktywność ta pozytywnie przekłada się na wizerunek instytucji kultury składający się z takich komponentów wyróżnionych przez D.A. Aakera [1991: 1] jak świadomość/skojarzenia związane 
z instytucją kultury, postrzeganie jakości jej oferty czy lojalność wobec instytucji kultury. Przyjęto następujące hipotezy badawcze:

- H1: konsumpcja, kontrybucja oraz kreacja w mediach społecznościowych treści dotyczących instytucji kultury pozytywnie wpływa na świadomość/ skojarzenia związane z instytucją kultury;

- H2: konsumpcja, kontrybucja oraz kreacja w mediach społecznościowych treści dotyczących instytucji kultury pozytywnie wpływa na postrzeganie jakości oferty instytucji kultury;

- H3: konsumpcja, kontrybucja oraz kreacja w mediach społecznościowych treści dotyczących instytucji kultury pozytywnie wpływa na lojalność wobec instytucji kultury.

W artykule konsumpcja, kontrybucja oraz kreacja treści w Internecie potraktowane zostały jako pojedyncza zmienna latentna i przewidywane jest jej skorelowanie oraz wywieranie przez nią pozytywnego wpływu na wizerunek instytucji kultury. Aby zweryfikować postawione hipotezy, w 2018 roku przeprowadzono badania ankietowe w grupie polskich odbiorców usług kultury, a zarazem osób które regularnie korzystają z mediów społecznościowych. Dane zgromadzone zostały za pomocą standaryzowanej ankiety internetowej. Próba w znacznym stopniu odzwierciedla profil grupy polskich internautów korzystających z mediów społecznościowych w Polsce - według badania Gemius. W badaniu wzięło udział 1837 respondentów. W wyniku weryfikacji odrzucono niekompletne oraz zawierające błędy kwestionariusze, a także kwestionariusze wypełnione przez respondentów, którzy odpowiedzieli, iż nigdy nie korzystali z mediów społecznościowych. Dało to ostatecznie 1021 poprawnie wypełnionych kwestionariuszy. Kobiety stanowiły 68,3\% próby, mężczyźni 31,7\%. Większość badanych (34,6\%) stanowili ludzie młodzi w wieku 29-38 lat oraz 19-28 lat (34,1\%). Najliczniejszą grupę stanowili respondenci z wykształceniem wyższym (69,7\%), 27,1\% respondentów to osoby z wykształceniem średnim (tabela 1).

Większość badanych zadeklarowała, że korzysta z usług instytucji kultury zazwyczaj raz w miesiącu (35,6\%). Są to najczęściej usługi takich instytucji jak: kino $(53,1 \%)$, biblioteka $(20,2 \%)$, teatr $(8,5 \%)$, dom czy centrum kultury $(6,6 \%)$, muzeum $(4,2 \%)$, filharmonia $(2,3 \%)$, galeria sztuki $(1,4 \%)$ oraz opera i operetka $(0,9 \%)$. Jednocześnie respondenci, przeglądając treści dotyczące instytucji kultury, najczęściej korzystają z takich mediów społecznościowych jak Facebook, Twitter lub Instagram. Badani jako zdecydowanie najpopularniejsze urządzenie do przeglądania treści w Internecie wskazują telefon komórkowy (smartfon - 96\%). Popularny jest także komputer stacjonarny (27,2\%), przenośny (laptop - 17\%) oraz tablet (notebook - 18,3\%).

By uchwycić aktywność badanych internautów w mediach społecznościowych (a zarazem odbiorców oferty instytucji kultury) poproszono ich o ustosunkowanie się do 15 stwierdzeń na siedmiostopniowej skali Likerta, rozciągającej się od 
odpowiedzi „bardzo rzadko” do „bardzo często”. Komponenty oraz poszczególne ich składowe służące do pomiaru aktywności internautów w mediach społecznościowych zaprezentowano w tabeli 2.

Tabela 1. Dane metryczkowe respondentów

\begin{tabular}{|c|c|c|c|c|c|}
\hline \multicolumn{2}{|r|}{ Dane metryczkowe } & \multirow{2}{*}{$\begin{array}{c}\text { Procent } \\
68,3\end{array}$} & \multicolumn{2}{|r|}{ Dane metryczkowe } & \multirow{2}{*}{$\begin{array}{r}\text { Procent } \\
3,6\end{array}$} \\
\hline \multirow{2}{*}{$\frac{y}{0}$} & Kobieta & & \multirow{6}{*}{$\begin{array}{l}\text { D } \\
\text { 苞 } \\
\text { N }\end{array}$} & Uczeń & \\
\hline & Mężczyzna & 31,7 & & Student & 13,7 \\
\hline \multirow{6}{*}{ 总 } & Do 18 lat & 2,2 & & Pracownik fizyczny & 11,5 \\
\hline & Od 19 do 28 lat & 34,1 & & Pracownik umysłowy & 66,4 \\
\hline & Od 29 do 38 lat & 34,6 & & Rencista/emeryt & 2,3 \\
\hline & Od 39 do 48 lat & 19,4 & & Osoba bezrobotna & 2,5 \\
\hline & Od 49 do 58 lat & 7,1 & \multirow{5}{*}{ 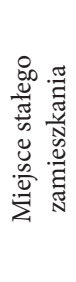 } & Wieś & 16,1 \\
\hline & Powyżej 58 lat & 2,7 & & Miasto do 50 tys. mieszkańców & 17,7 \\
\hline \multirow{8}{*}{ 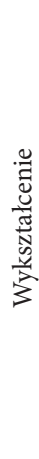 } & Podstawowe & 0,1 & & Miasto od 50 tyś. do 150 tyś. mieszkańców & 17,7 \\
\hline & Gimnazjalne & 1,8 & & Miasto od 150 tyś. do 500 tyś. mieszkańców & 16,8 \\
\hline & Zasadnicze zawodowe & 1,3 & & Miasto powyżej 500 tyś. mieszkańców & 31,6 \\
\hline & Średnie & 27,1 & \multirow{5}{*}{ 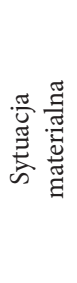 } & Bardzo zła & 1,3 \\
\hline & Wyższe & 69,7 & & Zła & 2,3 \\
\hline & & & & Przeciętna (ani dobra, ani zła) & 36,8 \\
\hline & & & & Dobra & 45,7 \\
\hline & & & & Bardzo dobra & 14 \\
\hline
\end{tabular}

Źródło: badania własne.

Stwierdzenia wykorzystane do pomiaru świadomości/skojarzeń związanych z instytucją kultury, postrzegania jakości oferty instytucji kultury oraz lojalności wobec instytucji kultury (łącznie 9 stwierdzeń) zostały zapożyczone $\mathrm{z}$ literatury przedmiotu i również dostosowane do siedmiostopniowej skali Likerta, rozciągającej się od odpowiedzi „zdecydowanie się nie zgadzam” do „zdecydowanie się zgadzam”. Świadomość/skojarzenia związane z instytucją kultury oraz postrzeganą jakość oferty instytucji kultury mierzono za pomocą sześciu stwierdzeń zaproponowanych przez B. Yoo i in. [Yoo, Donthu, Lee 2000: 1-14, Yoo, Donthu 2001] oraz A.F. Villarejo-Ramosa i M.J. Sánchez-Franco [2005]. Do pomiaru lojalności wobec 
instytucji kultury wykorzystano trzy stwierdzenia autorstwa G. Walsh i in. [2009: 187-203] (tabela 3).

Tabela 2. Komponenty służące do pomiaru aktywności internautów (a zarazem odbiorców oferty instytucji kultury) w mediach społecznościowych

\begin{tabular}{|c|c|c|c|}
\hline Lp. & $\begin{array}{l}\text { Komponent } 1 \\
\text { Konsumpcja treści } \\
\text { w Internecie }\end{array}$ & $\begin{array}{l}\text { Komponent } 2 \\
\text { Kontrybucja treści } \\
\text { w Internecie }\end{array}$ & $\begin{array}{c}\text { Komponent } 3 \\
\text { Kreacja treści } \\
\text { w Internecie }\end{array}$ \\
\hline 1 & $\begin{array}{l}\text { Oglądam oficjalną stronę } \\
\text { internetową wskazanej instytucji } \\
\text { kultury (1.1) }\end{array}$ & $\begin{array}{l}\text { Zamieszczam komentarze na } \\
\text { profilu społecznościowym wska- } \\
\text { zanej instytucji kultury }(2.1)\end{array}$ & $\begin{array}{l}\text { Piszę recenzje wydarzeń (oferty } \\
\text { kulturalnej) wskazanej przeze } \\
\text { mnie instytucji kultury (3.1) }\end{array}$ \\
\hline 2 & $\begin{array}{l}\text { Wchodzę na profile społecznoś- } \\
\text { ciowe (np. fanpage na Faceboo- } \\
\text { ku) (1.2) }\end{array}$ & $\begin{array}{l}\text { „Lubię” (lajkuję) posty wskazanej } \\
\text { instytucji kultury zamieszczane } \\
\text { na fanepage’u (2.2) }\end{array}$ & $\begin{array}{l}\text { Publikuję zdjęcia z wydarzeń } \\
\text { (eventów) wskazanej instytucji } \\
\text { kultury (3.2) }\end{array}$ \\
\hline 3 & $\begin{array}{l}\text { Czytam posty opublikowane } \\
\text { przez wskazaną instytucję } \\
\text { kultury w serwisach społecznoś- } \\
\text { ciowych (1.3) }\end{array}$ & $\begin{array}{l}\text { „Lubię” (lajkuję) zdjęcia, filmy } \\
\text { oraz inne grafiki wskazanej } \\
\text { instytucji kultury zamieszczane } \\
\text { na fanepage’u (2.3) }\end{array}$ & $\begin{array}{l}\text { Udostępniam posty dotyczące } \\
\text { wskazanej instytucji kultury } \\
(3.3)\end{array}$ \\
\hline 4 & $\begin{array}{l}\text { Czytam komentarze innych ludzi } \\
\text { na temat wskazanej przeze mnie } \\
\text { instytucji kultury zamieszczane } \\
\text { na platformach społecznościo- } \\
\text { wych (1.4) }\end{array}$ & $\begin{array}{l}\text { „Lubię" (lajkuję) strony } \\
\text { (fanpage'e) związane ze wskaza- } \\
\text { ną instytucją kultury (2.4) }\end{array}$ & $\begin{array}{l}\text { Udostępniam filmiki które } \\
\text { dotyczą wskazanej instytucji } \\
\text { kultury (3.4) }\end{array}$ \\
\hline 5 & $\begin{array}{l}\text { Oglądam zdjęcia, filmy oraz inne } \\
\text { grafiki związane ze wskazaną } \\
\text { instytucją kultury (1.5) }\end{array}$ & $\begin{array}{l}\text { Udostępniam, dzielę się z innymi } \\
\text { Internautami postami związa- } \\
\text { nymi ze wskazaną instytucją } \\
\text { kultury (2.5) }\end{array}$ & $\begin{array}{l}\text { Umieszczam treści związane ze } \\
\text { wskazaną instytucją kultury na } \\
\text { blogach (3.5) }\end{array}$ \\
\hline
\end{tabular}

Źródło: badania własne.

W analizach zastosowano kombinację statystyk eksploracyjnych oraz konfirmacyjnych. Po pierwsze, przeprowadzono analizę rzetelności trzech komponentów służących do pomiaru aktywności badanych internautów w mediach społecznościowych [Aczel, Sounderpandian 2017]. Przeprowadzono ją przy wykorzystaniu oprogramowania SPSS oraz modułu Analiza rzetelności. Jako model analityczny wybrano model wewnętrznej spójności alfa Cronbacha bazujący na przeciętnej korelacji pomiędzy pozycjami skali [Timm 2002] - w analizowanym przypadku wynosił on 0,945 . Wyniki oceny rzetelności narzędzia pomiarowego dla wszystkich 15 pytań wskazują zatem, że jest ono wysoce rzetelne po równi dla komponentów „Konsumpcja” (współczynnik alfa Cronbacha 0,881$)$, „Kontrybucja” $(0,925)$ i „Kreacja” $(0,906)$. 
Tabela 3. Komponenty systemu służącego do pomiaru świadomości/skojarzeń z instytucją kultury, postrzegania jakości oferty instytucji kultury oraz lojalności wobec instytucji kultury

\begin{tabular}{|l|l|l|l|}
\hline Lp. & \multicolumn{1}{|c|}{$\begin{array}{c}\text { Komponent 4 } \\
\text { Świadomość/skojarzenia } \\
\text { z instytucją kultury }\end{array}$} & $\begin{array}{c}\text { Komponent 5 } \\
\text { Postrzegana jakość oferty insty- } \\
\text { tucji kultury }\end{array}$ & $\begin{array}{c}\text { Komponent 6 } \\
\text { Lojalność wobec instytucji } \\
\text { kultury }\end{array}$ \\
\hline 1 & $\begin{array}{l}\text { Z łatwością rozpoznaję wskazaną } \\
\text { przeze mnie instytucję kultury } \\
\text { wśród innych podobnych orga- } \\
\text { nizacji (4.1) }\end{array}$ & $\begin{array}{l}\text { Oferta kulturalna wskazanej } \\
\text { przeze mnie instytucji jest dobrej } \\
\text { jakości (5.1) }\end{array}$ & $\begin{array}{l}\text { Regularnie korzystam z oferty } \\
\text { wskazanej przeze mnie instytu- } \\
\text { cji kultury (6.1) }\end{array}$ \\
\hline 2 & $\begin{array}{l}\text { Mam dobre wspomnienia } \\
\text { związane ze wskazaną instytucją } \\
\text { kultury (4.2) }\end{array}$ & $\begin{array}{l}\text { Oferta wskazanej instytucji } \\
\text { kultury jest lepszej jakości niż } \\
\text { innych podobnych organizacji } \\
(5.2)\end{array}$ & $\begin{array}{l}\text { Poleciłabym/poleciłbym wska- } \\
\text { zaną przeze mnie instytucję kul- } \\
\text { tury swoim znajomym (6.2) }\end{array}$ \\
\hline 3 & $\begin{array}{l}\text { Dobrze wiadomo, co wyróżnia } \\
\text { wskazaną instytucję kultury (4.3) }\end{array}$ & $\begin{array}{l}\text { Oferta wskazanej instytucji } \\
\text { kultury jest jedyna w swoim } \\
\text { rodzaju (5.3) }\end{array}$ & $\begin{array}{l}\text { Oferta kulturalna wskazanej } \\
\text { instytucji jest przeze mnie wy- } \\
\text { bierana w pierwszej kolejności } \\
(6.3)\end{array}$ \\
\hline
\end{tabular}

Źródło: badania własne.

Następnie przeprowadzono eksploracyjną analizę czynnikową z wykorzystaniem metody głównych składowych i ortogonalnej rotacji Promax przy użyciu oprogramowania SPSS [Konarski 2015]. Współczynnik adekwatności doboru próby Kaisera-Meyera-Olkina (KMO) przyjął wartość 0,937, natomiast test sferyczności Barletta okazał się istotny $(\chi 2=14121,423 ; p<0,001)$. Możliwość zastosowania analizy czynnikowej potwierdzona została również przez wartość p-value, która wynosi poniżej 0,001 . Otrzymane wyniki wskazały na odpowiednie ich dopasowanie do danych $-\mathrm{z}$ analizy nie wyeliminowano żadnej z użytych pozycji skal. Biorąc pod uwagę stopień wyjaśnienia zmienności wejściowego zbioru zmiennych, udało się wykryć dwa czynniki tłumaczące ponad 69\% informacji dla pełnego zestawu 15 zmiennych obserwowalnych (tabela 4).

Przy zastosowaniu rotacji ukośnej Promax zapewniającej występowanie związku pomiędzy czynnikami pokazano, że zależność ta jest na poziomie 0,659 , co oznacza zależność umiarkowanie silną dodatnią.

W dalszej części przeprowadzono analizę rzetelności komponentów służących do pomiaru komponentów wizerunku instytucji kultury (świadomość/skojarzenia związane z instytucją kultury, postrzeganie jakości oferty instytucji kultury oraz lojalność wobec instytucji kultury). Wykorzystane oprogramowanie oraz wszystkie założenia są analogiczne jak w przypadku omówionych wcześniej trzech komponentów służących do pomiaru aktywności badanych internautów w mediach społecznościowych. Otrzymane wyniki wskazały na ich dopasowanie do danych $\mathrm{z}$ analizy nie wyeliminowano żadnej z użytych pozycji skal. Biorąc pod uwagę 
stopień wyjaśnienia zmienności wejściowego zbioru zmiennych, udało się wykryć trzy czynniki tłumaczące ponad 77\% informacji dla pełnego zestawu 9 zmiennych obserwowalnych (tabela 5).

Tabela 4. Macierz ładunków czynnikowych (aktywność online w mediach społecznościowych) model pełny

\begin{tabular}{|c|c|c|c|}
\hline \multicolumn{4}{|c|}{ Macierz struktury } \\
\hline \multicolumn{2}{|r|}{ Stwierdzenie } & \multicolumn{2}{|c|}{ Składowa } \\
\hline $\mathrm{Nr}$ & Treść & 1 & 2 \\
\hline$(1.3)$ & $\begin{array}{l}\text { Czytam posty opublikowane przez wskazaną instytucję kultury w serwisach } \\
\text { społecznościowych }\end{array}$ & 0,883 & 0,583 \\
\hline$(2.3)$ & $\begin{array}{l}\text { „Lubię" (lajkuję) zdjęcia, filmy oraz inne grafiki wskazanej instytucji kultury } \\
\text { zamieszczane na fanepage’u }\end{array}$ & 0,878 & 0,677 \\
\hline$(2.2)$ & „Lubię” (lajkuję) posty wskazanej instytucji kultury zamieszczane na fanepage’u & 0,872 & 0,676 \\
\hline$(2.4)$ & „Lubię” (lajkuję) strony (fanpage’e) związane ze wskazaną instytucją kultury & 0,865 & 0,684 \\
\hline$(1.2)$ & Wchodzę na profile społecznościowe (np. fanpage na Facebooku) & 0,832 & 0,510 \\
\hline$(1.5)$ & $\begin{array}{l}\text { Oglądam zdjęcia, filmy oraz inne grafiki związane ze wskazaną instytucją } \\
\text { kultury }\end{array}$ & 0,825 & \\
\hline$(1.4)$ & $\begin{array}{l}\text { Czytam komentarze innych ludzi na temat wskazanej przeze mnie instytucji } \\
\text { kultury zamieszczane na platformach społecznościowych }\end{array}$ & 0,822 & 0,526 \\
\hline$(1.1)$ & Oglądam oficjalną stronę internetową wskazanej instytucji kultury & 0,557 & \\
\hline$(3.4)$ & Udostępniam filmiki które dotyczą wskazanej instytucji kultury & 0,604 & 0,895 \\
\hline$(3.3)$ & Udostępniam posty dotyczące wskazanej instytucji kultury & 0,631 & 0,894 \\
\hline$(3.5)$ & Umieszczam treści związane ze wskazaną instytucją kultury na blogach & & 0,857 \\
\hline$(3.2)$ & Publikuję zdjęcia z wydarzeń (eventów) wskazanej instytucji kultury & 0,528 & 0,797 \\
\hline$(2.5)$ & $\begin{array}{l}\text { Udostępniam, dzielę się z innymi Internautami postami związanymi ze wskaza- } \\
\text { ną instytucją kultury }\end{array}$ & 0,709 & 0,793 \\
\hline (3.1) & $\begin{array}{l}\text { Piszę recenzje wydarzeń (oferty kulturalnej) wskazanej przeze mnie instytucji } \\
\text { kultury }\end{array}$ & & 0,755 \\
\hline$(2.1)$ & $\begin{array}{l}\text { Zamieszczam komentarze na profilu społecznościowym wskazanej instytucji } \\
\text { kultury }\end{array}$ & 0,579 & 0,751 \\
\hline
\end{tabular}

Źródło: badania własne. 
Tabela 5. Macierz ładunków czynnikowych (wizerunek instytucji kultury) - model pełny

\begin{tabular}{|c|c|c|c|c|}
\hline \multicolumn{5}{|c|}{ Macierz struktury } \\
\hline \multicolumn{2}{|r|}{ Stwierdzenie } & \multicolumn{3}{|c|}{ Składowa } \\
\hline $\mathrm{Nr}$ & Treść & 1 & 2 & 3 \\
\hline$(4.2)$ & Mam dobre wspomnienia związane ze wskazaną instytucją kultury & 0,933 & 0,421 & $-0,009$ \\
\hline (4.3) & Dobrze wiadomo, co wyróżnia wskazaną instytucję kultury & 0,905 & 0,483 & $-0,020$ \\
\hline (4.1) & $\begin{array}{l}\text { Z łatwością rozpoznaję wskazaną przeze mnie instytucję kultury wśród } \\
\text { innych podobnych organizacji }\end{array}$ & 0,904 & 0,318 & $-0,005$ \\
\hline$(5.2)$ & $\begin{array}{l}\text { Oferta wskazanej instytucji kultury jest lepszej jakości niż innych } \\
\text { podobnych organizacji }\end{array}$ & 0,427 & 0,889 & 0,043 \\
\hline (5.3) & Oferta wskazanej instytucji kultury jest jedyna w swoim rodzaju & 0,262 & 0,864 & 0,027 \\
\hline$(5.1)$ & Oferta kulturalna wskazanej przeze mnie instytucji jest dobrej jakości & 0,622 & 0,788 & 0,045 \\
\hline (6.3) & $\begin{array}{l}\text { Oferta kulturalna wskazanej instytucji jest przeze mnie wybierana } \\
\text { w pierwszej kolejności }\end{array}$ & $-0,039$ & 0,057 & 0,853 \\
\hline$(6.2)$ & $\begin{array}{l}\text { Poleciłabym/poleciłbym wskazaną przeze mnie instytucję kultury } \\
\text { swoim znajomym }\end{array}$ & $-0,032$ & $-0,052$ & 0,848 \\
\hline (6.1) & Regularnie korzystam $\mathrm{z}$ oferty wskazanej przeze mnie instytucji kultury & 0,046 & 0,097 & 0,797 \\
\hline
\end{tabular}

Źródło: Badania własne.

Wyniki przeprowadzonej analizy pokazują, że udało się wygenerować trzy czynniki, które jednoznacznie odpowiadają komponentom systemu służącego do pomiaru świadomości/skojarzeń związanych z instytucją kultury, postrzeganej jakości oferty instytucji kultury oraz lojalności wobec instytucji kultury. Ładunki czynnikowe przyjmują wysokie wartości, świadcząc o bardzo silnej korelacji pomiędzy obserwowalnymi zmiennymi wejściowymi a ukrytymi czynnikami. Zaobserwowano umiarkowanie silną korelację pomiędzy czynnikiem 1 (świadomość/skojarzenia związane z instytucją kultury) a czynnikiem 2 (postrzeganie jakości oferty instytucji kultury), natomiast pomiędzy pozostałymi parami czynników zależności są bardzo słabe, co raczej sugeruje ich niezależność.

\section{Wplyw aktywności online użytkowników mediów spolecznościowych na wizerunek instytucji kultury - wyniki badania}

W celu przetestowania postawionych hipotez badawczych umieszczono wszystkie zmienne latentne w modelu równań strukturalnych (SEM). Analizę SEM przeprowadzono na podstawie modelu czynnikowego oszacowanego metodą głównych 
składowych w korespondencji do uzyskanych wyników, które nie zakładały eliminacji jakiejkolwiek zmiennej. Komponenty służące do pomiaru aktywności internautów (odbiorców usług kultury) w mediach społecznościowych analizowano jako czynnik drugiego rzędu składający się ze zmiennych latentnych pierwszego rzędu (konsumpcja, kontrybucja oraz kreacja). Z kolei system służący do pomiaru wizerunku instytucji kultury składał się z trzech zmiennych latentnych (świadomośćl skojarzenia z instytucją kultury, postrzegana jakość oferty instytucji oraz lojalność wobec instytucji kultury). Wyniki zaprezentowano w tabeli 6 .

Tabela 6. Współczynniki regresji w modelu SEM

\begin{tabular}{|c|c|c|c|c|c|c|c|}
\hline & Rela & & & ○ 光 & & & \\
\hline $\begin{array}{l}\text { Świa- } \\
\text { domość } \\
\text { instytucji } \\
\text { kultury }\end{array}$ & $\leftarrow$ & $\begin{array}{l}\text { Konsumpcja } \\
\text { kontrybucja, } \\
\text { kreacja treści } \\
\text { w Internecie }\end{array}$ & 0,404 & 0,229 & 0,063 & 6,369 & $<0,001^{\star}$ \\
\hline $\begin{array}{l}\text { Postrzega- } \\
\text { nie oferty } \\
\text { instytucji } \\
\text { kultury }\end{array}$ & $\leftarrow$ & $\begin{array}{l}\text { Konsumpcja } \\
\text { kontrybucja, } \\
\text { kreacja treści } \\
\text { w Internecie }\end{array}$ & 0,337 & 0,252 & 0,053 & 6,379 & $<0,001^{\star}$ \\
\hline $\begin{array}{l}\text { Lojalność } \\
\text { wobec } \\
\text { instytucji } \\
\text { kultury }\end{array}$ & $\leftarrow$ & $\begin{array}{l}\text { Konsumpcja } \\
\text { kontrybucja, } \\
\text { kreacja treści } \\
\text { w Internecie }\end{array}$ & 0,069 & 0,049 & 0,053 & 1,310 & 0,190 \\
\hline
\end{tabular}

Źródło: badania własne

Wyniki zamieszczone w tabeli 6 wskazują, że zaobserwowano dodatni wpływ wszystkich trzech komponentów służących do pomiaru aktywności internautów (odbiorców usług kultury) w mediach społecznościowych na komponenty systemu służącego do pomiaru wizerunku instytucji kultury, jednakże statystyczną istotność $\left({ }^{*}\right)$ potwierdzono tylko dla relacji komponentu takiego jak „świadomość/skojarzenia związane z instytucją kultury” oraz dla komponentu „postrzeganie jakości oferty instytucji kultury". Związki są dodatnie, co oznacza, że komponenty te działają stymulująco na poszczególne składowe (komponenty) wizerunku instytucji kultury. Tym samym wraz ze wzrostem aktywności działań internautów w mediach społecznościowych zwiększa się poziom świadomości instytucji kultury oraz postrzeganie jakości oferty instytucji kultury. Siłę wpływu mierzy standaryzowany współczynnik 
regresji - wpływ ten jest słaby, ale porównywalny. Natomiast dla relacji z lojalnością wobec instytucji kultury wpływ ten okazuje się znikomy, co jest powiązane z brakiem istotności dla tej relacji. Komentując ostatecznie wyniki z przeprowadzonej analizy i odnosząc je do postawionych hipotez badawczych, stwierdzono, że:

- H1: konsumpcja, kontrybucja oraz kreacja w mediach społecznościowych treści dotyczących instytucji kultury pozytywnie wpływa na świadomośćl skojarzenia związane z instytucją kultury - została potwierdzona;

- H2: konsumpcja, kontrybucja oraz kreacja w mediach społecznościowych treści dotyczących instytucji kultury pozytywnie wpływa na postrzeganie jakości oferty instytucji kultury - została potwierdzona;

- H3: konsumpcja, kontrybucja oraz kreacja w mediach społecznościowych treści dotyczących instytucji kultury pozytywnie wpływa na lojalność wobec instytucji kultury - nie została potwierdzona.

Należy zatem zastanowić się, co ma istotny wpływ na taki wynik. Samo konsumowanie treści przez internautów, ich śledzenie („polubienie”) profilu instytucji kultury na portalu takim jak Facebook może być dla użytkowników bardzo korzystne, a zarazem nie wiąże się dla internauty z żadnym zobowiązaniem wobec instytucji kultury. Ponadto z badań przeprowadzonych dla MuseumNext na 500 rezydentach Wielkiej Brytanii wynika, że osoby, które śledzą w mediach społecznościowych profil wybranej instytucji kultury (konsumują treści dotyczące instytucji kultury), robią to głównie, gdyż chcą [Social Media Audiences and the Museum]:

- udzielić wsparcia w promocji tej instytucji (47\%),

- zaimponować znajomym tym, że odwiedziły tę instytucję (38\%),

- pozyskać zniżki promocyjne lub zobaczyć zapowiedzi zbliżających się wystaw (35\%),

- utożsamiać się z opiniami lub stylem reprezentowanym przez daną instytucję kultury w mediach społecznościowych (31\%),

- odwiedzić daną instytucję kultury (20\%),

- poinformować swoich znajomych o tym, że doceniają oni instytucję kultury $(11 \%)$.

Z badań tych można zatem wyciągnąć wniosek, że platformy instytucji kultury w mediach społecznościowych mogą być atrakcyjne same w sobie dla użytkowników tych mediów, co sprawia, iż internauci chętnie konsumują treści dotyczące instytucji kultury, a często nawet dzielą się swoimi opiniami na jej temat (kontrybucja). Konsumpcja i kontrybucja treści nie wiąże się zazwyczaj z dużym wysiłkiem intelektualnym dla użytkownika mediów społecznościowych, dlatego też tę aktywność można zaobserwować najczęściej. Trzeci komponent - kreacja treści dotyczących instytucji kultury w mediach społecznościowych wymaga od użytkowników internetu zdecydowanie większego zaangażowania aniżeli tylko konsumpcja treści czy kontrybucja. Wymaga często od nich również specjalistycznej wiedzy oraz odpowiednich umiejętności (np. przygotowanie grafiki czy krótkiego filmu), dlatego też tego typu zaangażowanie 
występuje w przestrzeni internetu zdecydowanie rzadziej aniżeli wspomniana wcześniej konsumpcja czy kontrybucja. Sama konsumpcja treści czy kontrybucja mają zapewne duży wpływ na świadomość instytucji kultury a nawet postrzeganie jakości jej oferty. W procesie budowania lojalności wobec instytucji kultury najbardziej istotna będzie jednak kreacja treści, która, jak już zaznaczono, jest aktywnością online występującą stosunkowo rzadko. Najprawdopodobniej wiąże się to $\mathrm{z}$ faktem, iż nie odnotowano statystycznie istotnego związku dla wpływu aktywności online użytkowników mediów społecznościowych na lojalność wobec instytucji kultury.

\section{Wnioski $z$ badań - implikacje dla zarządzania}

W drugiej dekadzie XXI wieku następują istotne zmiany jakościowe, wpływające na nowe możliwości kształtowania wizerunku instytucji kultury, m.in. wykorzystujące do tego internet. Jak pokazano w artykule, aktywność internautów w mediach społecznościowych stymulująco wpływa na świadomość/skojarzenia związane z instytucją kultury oraz postrzeganie jakości jej oferty. Z badań przeprowadzonych przez M. Sobocińską [2015: 214] można wyciągnąć jednak wniosek, że nie wszyscy menedżerowie instytucji kultury są tego w pełni świadomi. Pomimo iż prawie wszystkie badane instytucje kultury w Polsce (badaniu poddanych zostało 451 instytucji) posiadały własną stronę internetową $(99,1 \%)$, to profil na Facebooku posiadło już tylko 77,4\% instytucji kultury poddanych badaniu. Osoby zarządzające instytucjami kultury w Polsce do głównych celów wykorzystywania mediów społecznościowych zaliczają kształtowanie wizerunku instytucji kultury, budowanie relacji z odbiorcami kultury oraz reklamowanie instytucji kultury. Wskazało na to odpowiednio $71,2 \%, 51,3 \%$ oraz $44,9 \%$ badanych. Wszystkie trzy odpowiedzi związane są zatem z wizerunkiem instytucji kultury, mają bowiem istotny wpływ na świadomość instytucji, postrzeganie jakości jej oferty czy lojalność wobec niej. Z badań Sobocińskiej wynika dodatkowo, iż media społecznościowe zyskują w Polsce na znaczeniu i stają się coraz bardziej istotnym narzędziem komunikacji instytucji kultury z rynkiem [Sobocińska 2015]. Inne badania, przeprowadzone przez Pew Research Center na 1244 organizacjach pozarządowych działających w USA dowodzą, że amerykańskie instytucje kultury w działaniach mających na celu kształtowanie wizerunku wykorzystują głównie takie media społecznościowe, jak Facebook (99\%), Twitter (74\%), YouTube (67\%), Flickr (38\%), LinkedIn (31\%), Wikipedia (27\%), Vimeo (23\%), Foursquare (20\%), Yelp (19\%) czy Google+ (17\%) [Thomson i in. 2013]. Spośród badanych organizacji 12,2\% ma założone cztery platformy w mediach społecznościowych, $11,9 \%$ posiada trzy platformy, $11,3 \%$ pięć platform, $11,1 \%$ dwie platformy, a 10,6\% aż sześć [Thomson, Purcell, Rainie 2013: 27]. Warto przy tym zaznaczyć, że co czwarta organizacja zamieszcza treści w mediach społecznościowych kilka razy na dzień (25\%), a co piąta raz na dzień (20\%). Ponadto $28 \%$ publikuje je kilka 
razy na tydzień, a 16\% raz w tygodniu. Podobnie jak z badań Sobocińskiej wynika $\mathrm{z}$ nich zatem, że rola mediów społecznościowych jest bardzo duża i należy się spodziewać, iż w najbliższych latach będzie jeszcze bardziej znacząca [Sobocińska 2015]. Podobne wnioski można wyciągnąć także z badań prowadzonych przez autora, które realizowane były w instytucjach kultury na obszarze Euroregionu Śląsk Cieszyński w 2015 i 2016 roku [Wróblewski 2016, 2017]. Wynika z nich bowiem, że na przestrzeni ostatnich lat zwiększył się w działaniach marketingowych instytucji kultury zakres stosowanych mediów społecznościowych. Świadczą o tym wysokie odsetki polskich i czeskich instytucji kultury, które od przynajmniej jednego roku, ale nie dłużej niż pięć lat posiadają profil już nie tylko na Facebooku (66,5\%), ale również Twitterze (48,5\%), Instagramie (32\%) czy kanał na YouTubie (15,5\%). Należy to zatem postrzegać jako odpowiedź instytucji kultury na nowe trendy w zachowaniach konsumentów, które są związane z wirtualizacją procesu pozyskiwania informacji czy podejmowania przez odbiorcę i potencjalnego odbiorcę oferty instytucji kultury decyzji zakupu. Można założyć, że będzie się to przekładać również na rosnącą aktywność polskich odbiorców usług kultury w mediach społecznościowych (konsumpcja, kontrybucja, kreacja treści), a tym samym media te staną się kluczowym instrumentem kształtowania wizerunku instytucji kultury.

Sięgając po media społecznościowe w procesie kształtowania wizerunku instytucji kultury, należy jednak pamiętać, że media te rządzą się innymi prawami niż typowe narzędzia komunikacji marketingowej. W szczególności istotne są otwartość, przejrzystość, nieformalność oraz równoprawność użytkowników. Ważną implikacją tych cech jest gotowość do szczerego dialogu z użytkownikami. Menedżerowie instytucji kultury muszą zdawać sobie sprawę z tego, że interakcje z internautami mogą być zarówno pozytywne, jak i negatywne, co zarówno w dodatni, jak i ujemny sposób może przekładać się na wizerunek instytucji. Trudne są zwłaszcza te drugie interakcje, krytykujące instytucję kultury, prezentowane inicjatywy i tematy. Za przykład posłużyć mogą chociażby napastliwe komentarze internautów do niektórych wpisów artystów pojawiających się na portalach społecznościowych czy często niemerytoryczne komentarze materiałów filmowych zamieszczanych na kanale YouTube. Poza tym wciąż pozostaje racjonalna i merytoryczna krytyka publikowanych treści i działań, których one dotyczą, a której często nie można przemilczeć i nie zauważyć. Jej istnienie wymaga od instytucji kultury określenia odpowiednich wytycznych postępowania w takich przypadkach. Oczywiście istnieje też opcja wyłączenia możliwości komentowania, ale zamyka to bezcenny kanał sprzężenia zwrotnego, dzięki któremu instytucja może nie tylko kształtować swój wizerunek, ale również doskonalić swoje działania i dopasowywać je coraz lepiej do potrzeb swoich odbiorców [Kopera, Najda-Janoszka, Wszendobył-Skulska 2014]. Należy pamiętać, że to od dobrego przygotowania instytucji kultury będzie w dużym stopniu zależeć, czy przedsięwzięcie kształtowania wizerunku z wykorzystaniem aktywności użytkowników w mediach społecznościowych okaże się sukcesem, czy porażką. 


\section{Biblioggrafia}

Aaker D.A. (1991) Managing brand equity: Capitalizing on the value of a brand name, New York: The Free Press.

Aaker D.A. (1996), Measuring brand equity across products and markets, „California Management Review", Vol. 38, Issue 2, s. 102-120.

Aaker D.A., Joachimsthaler E. (2000) Brand leadership. Building assets in an information econo$m y$, New York: The Free Press.

Aczel A.D., Sounderpandian J. (2017) Statystyka w zarządzaniu, red. nauk. przekł. B. Witkowski, Warszawa: Wydawnictwo PWN.

Budzyński W. (2003), Wizerunek firmy. Kreowanie, zarządzanie, efekty, Warszawa: Poltext.

Correia T.J.F., Mateus A., Leonor S. (2015), Marketing Communications Model for Innovation Networks, „International Journal of Innovation”, Vol. 3, Issue 2, s. 43-53.

Golinowski, J. (2005), Dylematy wizerunku instytucji publicznej, Warszawa: Oficyna Wydawnicza ASPRAJR.

Grzesiak M. (2018), Personal brand creation in the digital age. Theory, Research and Practice, Warszawa: Palgrave Pivot.

Hartmann R. (1992), Strategische Marketingplanung im Einzelhandel - Kritische Analyse spezifischer Planungsinstrumente, Wiesbaden: Deutscher Universitäts Verlag.

Kaplan A.M., Haenlein M. (2010), Users of the world, unite! The challenges and opportunities of Social Media, „Business Horizons”, Vol. 53, Issue 1, s. 59-60.

Keller K.L. (1993), Conceptualizing, measuring, and Managing Customer-Based Brand Equity, „Journal of Marketing”, Vol. 57, Issue 1, s. 1-22.

Killian G., McManus K.A. (2015), Marketing Communications Approach for the Digital Era: Managerial Guidelines for Social Media Integration, „Business Horizons”, Vol. 58, Issue 5, s. 539-549.

Konarski R. (2015), Modele równań strukturalnych. Teoria i praktyka, Warszawa: Wydawnictwo PWN.

Kopera S., Najda-Janoszka M., Wszendobył-Skulska, E. (2014), Kanał YouTube jako przykład wykorzystania mediów społecznościowych w procesie transferu wiedzy do biznesu turystycznego, „Folia Turistica”, nr 32, s. 55-72.

Kotler P., Haider D.H., Rein I. (1993), Marketing Places. Attracting Investment, Industry and Tourism to Cities, States and Nations, New York: The Free Press.

Lippmann W. (1998), Public Opinion, New Brunswick - London: Tuchstone Books.

Mazurek-Łopacińska K., Sobocińska M. (2017), Media społecznościowe w procesach komunikacji przedsiębiorstwa z rynkiem, „Marketing i Zarządzanie”, nr 1 (47), s. 343-352.

Mruk H. (2012), Marketing. Satysfakcja klienta i rozwój przedsiębiorstwa, Warszawa: Wydawnictwo PWN.

Muntinga D.G., Moorman M., Smit E.G. (2011), Introducing COBRAs: Exploring motivations for brand-related social media use, „International Journal of Advertising”, Vol. 30, Issue 1, s. 13-46. 
Murdoch A. (2003), Komunikowanie w kryzysie. Jak ratować wizerunek firmy, Warszawa: Wydawnictwo Poltext.

Schivinski B., Brzozowska-Woś M. (2015), Badanie aktywności online polskich konsumentów dotyczacej marek, „e-mentor”, nr 2 (59), s. 77-85.

Selase A.E. (2018), Building Image in the Airline Industry. Pakistan International Airline as the Point of Convergence, „International Journal of Recent Advances in Multidisciplinary Research", Vol. 5, Issue 5, s. 3830-3834.

Shao G. (2009), Understanding the appeal of user-generated media: A uses and gratification perspective, „Internet Research”, Vol. 19, Issue 1.

Smith P.R., Zook Z. (2011), Marketing Communications: Integrating Offline and Online with Social Media, London: Kogan Page Publishers.

Sobocińska M. (2015), Uwarunkowania i perspektywy rozwoju orientacji rynkowej w podmiotach sfery kultury, Wrocław: Wydawnictwo Uniwersytetu Ekonomicznego we Wrocławiu.

Social Media Audiences and the Museum [dok. elektr.], dostęp online: http://www.museumnext. org/2010/blog/ research-social- media-audiences-and-the-museum [odczyt: 10 marca 2018].

Szyszka M. (2013), Kształtowanie wizerunku instytucji pomocy społecznej w mediach, Warszawa: Centrum Rozwoju Zasobów Ludzkich.

Thomson K., Purcell K., Rainie L. (2013), Arts Organizations and Digital Technologies, „Pew Research Center”, Vol. 1, https://www.pewinternet.org/wp-content/uploads/sites/9/media/ Files/Reports/2013/PIP_ArtsandTechnology_PDF.pdf

Timm N.H. (2002), Applied Multivariate Analysis, Heidelberg: Springer.

Villarejo-Ramos A.F., Sánchez-Franco M.J. (2005), The impact of marketing communication and price promotion on brand equity, ,Journal of Brand Management”, Vol. 12, Issue 6, s. 431-445.

Walsh G., Mitchell V.W., Jackson P.R., Beatty S.E. (2009), Examining the antecedents and consequences of corporate reputation: A customer perspective, „British Journal of Management”, Vol. 20, Issue 2, s. 187-203.

Wróblewski Ł. (2016), Marketing strategiczny w sektorze kultury Euroregionu Śląsk Cieszyński, Warszawa: CeDeWu.

Wróblewski Ł. (2017), Culture Management. Strategy and Marketing Aspects, Berlin: Logos Verlag. Wróblewski Ł., Bilińska-Reformat K., Grzesiak M. (2018), Sustainable Activity of Cultural Service Consumers of Social Media Users - Influence on the Brand Capital of Cultural Institutions, „Sustainability”, Vol. 10, https://www.mdpi.com/2071-1050/10/11/3986/htm [odczyt: 15 grudnia 2018].

Yoo B., Donthu N., Lee S. (2000), An examination of selected marketing mix elements and brand equity, „Journal of the Academy of Marketing Science”, Vol. 28, Issue 2, s. 1-14.

Yoo B., Donthu N. (2001), Developing and validating a multidimensional consumer-based brand equity scale, „Journal of Business Research”, Vol. 52, Issue 1, s. 1-14. 